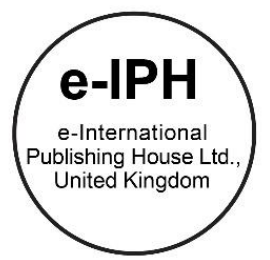

\title{
Examination of the Relationship between Urban Air Pollution and Urban Planning Decisions in Cigli Case, Izmir (Turkey)
}

\author{
Nur Sinem Ozcan*, K. Mert Cubukcu \\ Department of City and Regional Planning, Architecture Faculty, Izmir Dokuz Eylul University, Izmir, 35160, Turkey
}

\begin{abstract}
The air pollution problem remains, although significant improvements have been seen in urban air quality over the last years. Despite the size and variety of studies on urban air pollution, the usage of spatial statistics has been extremely limited. This study aims to show that the spatial statistic techniques can well be used to examine and explain the air pollution levels in urban areas. The data for the sulphur dioxide (SO2) and nitrogen dioxide (NO2) concentrations are measures using passive diffusion tubes at the 67 monitoring sites in the district of Çiğli (Izmir), which are selected through a spatial systematic sampling process. The tubes were exposed for a 2-week period in August 2015. For the determination of the level of clustering for high values and low values of $\mathrm{SO} 2$ and NO2 concentrations, Getis-Ord G* local statistics are calculated. There are five points with high values of SO2 surrounded by low values, three points of NO2, where the results are statistically significant at the 0.10 level. The findings indicate that the presence of the industrial zone, the form of fossil fuels (coal or natural gas) used in heating, and topography are the strong determinants urban air pollution.
\end{abstract}

(C) 2016. The Authors. Published for AMER ABRA by e-International Publishing House, Ltd., UK. Peer-review under responsibility of AMER (Association of Malaysian Environment-Behaviour Researchers), ABRA (Association of Behavioural Researchers on Asians) and cE-Bs (Centre for Environment-Behaviour Studies), Faculty of Architecture, Planning \& Surveying, Universiti Teknologi MARA, Malaysia.

Keywords: Urban air pollution; planning decisions; spatial autocorrelation; air pollutants

\section{Introduction}

The air pollution problem remains, although significant improvements have been seen in urban air quality over the last years. As a result of dense energy consumption, economic development with population growth and urbanization, the levels of air pollutants have increased and emissions of many pollutants are growing especially in metropolitan areas. Urban population growth, combined with change in land use through urban planning decisions, is among major reasons for the air quality problem (Mayer, 1999). Dense buildings and population, different urban activities, the increasing automobiles ownership, and the total

\footnotetext{
* Corresponding author. Tel.: +90-232-301-8470 ; fax: +90-232-453-2986.

E-mail address: spartigoc@gmail.com
}

(C) 2016. The Authors. Published for AMER ABRA by e-International Publishing House, Ltd., UK. Peer-review under responsibility of AMER (Association of Malaysian Environment-Behaviour Researchers), ABRA (Association of Behavioural Researchers on Asians) and cE-Bs (Centre for Environment-Behaviour Studies), Faculty of Architecture, Planning \& Surveying, Universiti Teknologi MARA, Malaysia.

DOI: https://doi.org/10.21834/e-bpj.v1i2.267 
number of vehicles in traffic can be generalized as the primarily reasons air pollution that affects urban areas (Mansha et al., 2012). In addition to these urban activities, different factors are significant contributors to reduce of urban air quality such as the reliance on fossil fuels in warming, industrial activities and traffic, dependence on the private automobiles, inefficient use of energy in buildings and public transportation, the use of incorrect and incomplete combustion techniques, the degradation of open and green areas, etc. (Grsic et al., 2014, Dimitrovski et al., 2015, Bouhouras and Basbas, 2015). Air pollution in urban areas affects not only urban air quality, also quality of life, and public health directly (Deak et al., 2015, Borhan et al., 2013), and these circumstances lead to shift in planning decisions.

Urban planning focuses on the use of land and design of the urban environment, thus ensuring the development of the metropolitan areas. It aims to provide a secure, organized, and enjoyable city life for residents of both new and existing towns, concerning building locations, open and green spaces, zoning, transportation, and city aesthetics. Within the urban planning process, three key elements of urban quality of life can be selected to focus on: residential preferences, mobility and accessibility and green spaces. These three elements are actually interlinked and overlapping because urban quality of life is the result of network between these dimensions (El Din et al., 2013). The environmental urban quality of life is one of the main dimensions of urban quality of life and the concept of urban air quality has been associating with the environmental urban quality of life in urban areas (Turkoglu, 2015).

The empirical studies focusing on the relation between urban planning decisions and the level of air pollution have been limited, although urban planning decision including population density, site selection of industrial zones, and planning of green areas are closely related to the observed level of the concentrations of pollutants. The results of empirical studies have shown that the concentrations of pollutants are still increasing, and they are over the acceptable limit values in most of the largely populated cities in especially developing countries during the winter season (Ozcan and Cubukcu, 2015).

In parallel to these inevitable changes in urban areas, planning decisions that interfere directly with the physical environment and current land use can be criticized as an opportunity to increase the urban air quality, such as site selection of industrial activities. The purpose of the study is to examine the concentrations of two common air polluters (sulfur dioxide (SO2) and nitrogen dioxide (NO2)) with regard to the urban land use decisions. The spatial distributions of the pollution levels are analyzed using a well-known local spatial autocorrelation technique, the Getis-Ord G* local statistic.

\section{Literature Review}

There exists a sizeable amount of literature on urban air quality and its effects on urban areas. These studies vary in terms of their focus (the type of pollutant, the source of pollutant, spatial scale, the measurement period, etc.). A number of studies examine the source of pollutant. Bayram (2008), İncecik (1994), Colls (2002) and Fenger (2002) suggest that the primary air pollutants in urban areas are sulphur dioxide (SO2), particulate matter (PM10 and PM2.5), nitrogen dioxide (NO2), carbon monoxide (CO) and ozone (O3). The high level of urban air pollution is caused by a continuous increase in the number of dense population in urban areas, the increase in the number of motor vehicles in traffic parallel to the population variance, unplanned urbanization and industrialization in city centers, the use of incorrect and incomplete combustion techniques in the domestic heating and industrial processes, meteorological and topographical conditions of cities as important sources of urban air pollution.

Another set of studies examine the type of pollutant. Briggs et al. (2008), Mayer (1999), Ahmad and Aziz (2013) focus on nitrogen dioxide (NO2) that is a secondary pollutant and derived from especially motor vehicles. Brauer et al. (2003) and Nerriere et al. (2005) focus on particulate matter (PM10 and PM2.5) as an urban air pollutant causes a decrease in the level of air quality, while the level of individual exposure to pollution increases in urban areas. Dalyan and İncecik (2002), Pinto et al. (1998) and Bayram (2008) focus on sulphur dioxide (SO2) that decreases air quality dramatically in high dense residential areas and industrial areas and is a substantial and widespread pollutant.

In the literature, a number of studies examine the measurement period of urban air pollutants. Mukerjee et al (2012), Reche et al. (2012), Zhu et al. (2011), and Vallius et al. (2004) examine the measurement studies carried out only one period (summer or winter) during different periods. Similarly, these studies suggest that the level of air pollution differs according to the measurement period. Shendell et al (2012), Kocaman (2010), Coşkun (2008), Mönkkönen et al (2004), Shi et al. (2003) and Wehner et al. (2002) focus on the measurement studies carried out both summer and winter in the same year during different periods (one week, two weeks, one month, three months, etc.). In comparison to the measurement results of summer period, the level of urban air pollution (SO2 and PM10) is higher in urban areas in the winter period because of the use of coal in domestic 
heating, incorrect combustion techniques. According to the measurement results of summer period, the level of air pollution (NO2 and $\mathrm{O} 3$ ) increase depending the increase of motor vehicles in traffic due to the decrease of population in cities and photochemical reactions in the atmosphere.

The scale and scope of the studies vary. Lee et al. (2013), Lin et al. (2013), Zbieranowski and Aherne (2012), Evci (2009) and Yang et al. (2005) focus on regional studies worldwide. The results of these studies differ according to the size of study area, land use, meteorological and topographical factors and population density in the regions. Fan et al. (2012), Mansha et al. (2012), Mukerjee (2012), Pits et al. (2008), Moore et al (2007) and Querola et al. (2001) focus on urban studies which observe the level of urban air pollution in different cities all around the world. They suggest that the concentrations of air pollutants in urban areas increase various factors such as because of dense building and population, widespread use of automobiles instead of public transportation, the location of industrial facilities near city centers and the negative effects of land use decisions on the level of air quality.

Despite the size and variety of studies on urban air pollution, the usage of spatial statistics has been extremely limited. This study aims to show that the spatial statistic techniques can well be used to examine and explain the air pollution levels in urban areas.

\section{Research Method}

In this study, a well-known local spatial autocorrelation technique, Getis-Ord G* local statistic (Getis and Ord, 1992, Ord and Getis, 1995), is used to examine the spatial concentrations of SO2 and NO2 differ across the study area. The spatial autocorrelation explains a dependency between variables in neighborhood locations or a systematic pattern of values across the locations on a map (Griffith, 2009). Also, the spatial autocorrelation measures the correlation of a variable with itself through space and it can be positive or negative. Positive spatial autocorrelation occurs when similar values occur near one another. Negative spatial autocorrelation occurs when dissimilar values occur near one another (Gunaratna, 2013). The Moran coefficient (MC) and the Geary ratio (GR) are the most commonly used quantitative global indices in spatial autocorrelation, and they each produce a single index to examine the spatial distribution of point data with an attached variable value. However, in the case of local spatial autocorrelation techniques, an index value is produced for each point data, and the hypotheses are tested at the point point, or local level. For the determination of the level of clustering for high values and low values in the study area, GetisOrd $G^{*}$ local statistics are calculated. In the local version of $G$ statistics, the $z$-scores of these points show where hot spots or cold spots exist in the study area. The hot spots have a high variable value surrounded by points with low values, and cold spots have a low value surrounded by points with high variable values. The Getis-Ord $G^{*}$ local statistics for spatial autocorrelation for point $\mathrm{i}\left(\mathrm{G}^{*} \mathrm{i}\right)$ can be written as (Cubukcu, 2015, Getis and Ord, 1992, Ord and Getis, 1995):

$$
G_{i}^{*}=\frac{\sum_{j} w_{i j} x_{j}}{\sum_{j} x_{j}}
$$

where $\mathrm{n}$ is the number of sample size, wij is the spatial weight between $\mathrm{i}$ and $\mathrm{j}$ points, $\mathrm{d}$ is the distance and $\mathrm{xj}$ is the variable value of $\mathrm{j}$ point.

\section{Data and Study Area}

Izmir city is one of the largest cities in Turkey with a total population of 4.113 .072 by the year 2015 . The study area is the district of Çiğli. It is located in the northern part of Izmir Metropolitan area and has a population of 176.864 by the year 2014. In the district's area, there exists an industrial zone (Ataturk Organized Industrial Zone), a very large recreational area including one of the largest zoos in Turkey (Sasalı Natural Life Park), a military zone including a military airport, a regional railway station, commercial areas and residential areas in differing densities. The study area is represented in Figure 1. 

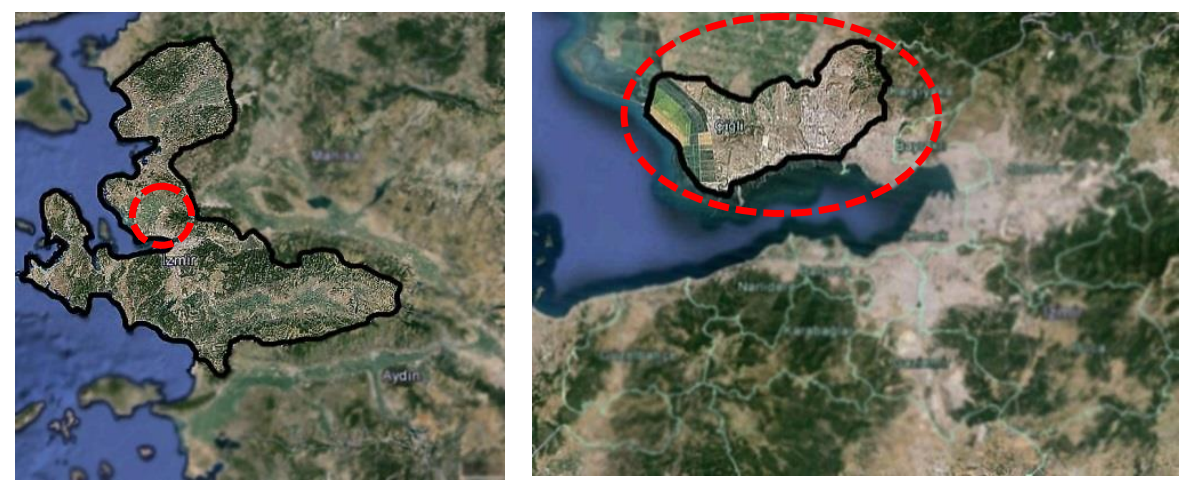

Fig. 1. The study area (Izmir, The District of Cigli)

The data for the sulfur dioxide (SO2) and nitrogen dioxide (NO2) concentrations are measured using passive diffusion tubes at the 80 monitoring sites, exposed for a 2-week period in Çiğli in August 2015. In the study area, totally 80 observation points are selected using spatial systematic sampling. Because of different reasons, data from 13 of the passive diffusion tubes were unusable and so there are a total of 67 observations in the data set. The descriptive statistics for the observed SO2 and NO2 levels, the values of average temperature, precipitation and pressure are presented in Table 1.

Table 1. The descriptive statistics of the parameters for the monitoring sites at the district level $(n=67)$

\begin{tabular}{lllll}
\hline Parameters & Minimum & Maximum & Mean & Std. Deviation \\
\hline SO2 $(\mu \mathrm{g} / \mathrm{m} 3)$ & 0.40 & 16.00 & 3.88 & 2.98 \\
NO2 $(\mu \mathrm{g} / \mathrm{m} 3)$ & 5.7 & 100.9 & 39.41 & 1.51 \\
Average Temperature $(\mathrm{oC})$ & 5.58 & 16.58 & 11.47 & 3.537 \\
Average Precipitation (Milimeters) & 0.00 & 152.00 & 30.43 & 47.252 \\
Average Pressure $(\mathrm{hPa})$ & 1004.77 & 1021.10 & 1014.87 & 5.793 \\
\hline
\end{tabular}

As seen in Table 1, the values of sulfur dioxide (SO2) concentrations vary between 0.4 and $16 \mu \mathrm{g} / \mathrm{m} 3$, with a mean of 3.876 $\mu \mathrm{g} / \mathrm{m} 3$. In the center, northern and southern parts of the study area, SO2 concentrations are higher than other parts. The intensive use of non-natural gas (coal/wood) in the domestic heating is one of the main reasons for this increase. The weighted spatial distribution of polluter (SO2) depending on the concentrations is presented in Figure 2. As seen in Table 1, the values of nitrogen dioxide (NO2) concentrations vary between 5.7 and $100.9 \mu \mathrm{g} / \mathrm{m} 3$, with a mean of $39.41 \mu \mathrm{g} / \mathrm{m} 3$. The increase of motor vehicles in traffic in the Çiğli district causes an increase in NO2 concentrations. Similarly, NO2 concentrations are higher than in the center, south and north parts of the study area. The weighted spatial distribution of polluter (NO2) depending on the concentrations is presented in Figure 3. As seen in Table 1, the average temperature values vary between 5.58 and 16.58 oC, with a mean of $11.47 \mathrm{oC}$. The average precipitation values vary between 0 and $152 \mathrm{~mm}$, with a mean of $30.43 \mathrm{~mm}$. The average pressure values vary between 1004.77 and $1021.10 \mathrm{hPa}$, with a mean of $1014.87 \mathrm{hPa}$ in the study area. 


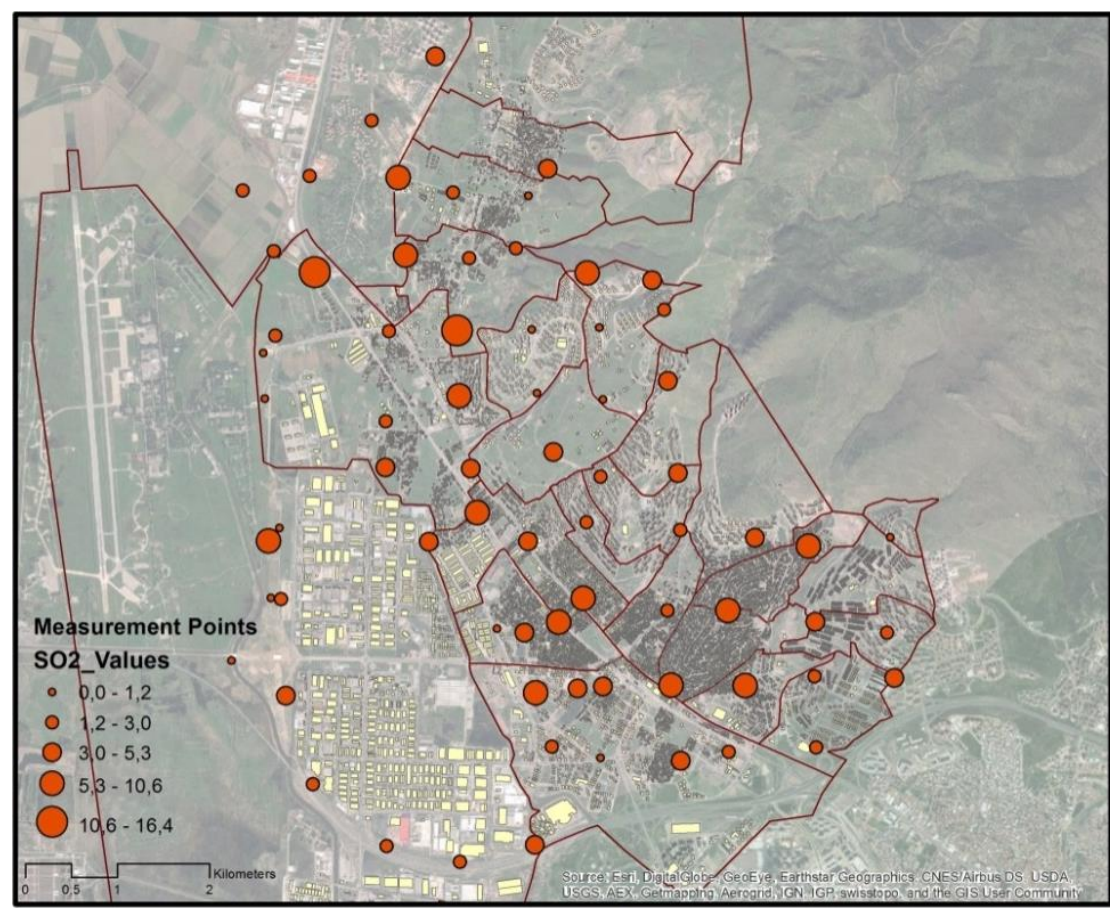

Fig. 2. The observed concentrations for $\mathrm{SO} 2(\mu \mathrm{g} / \mathrm{m} 3)$

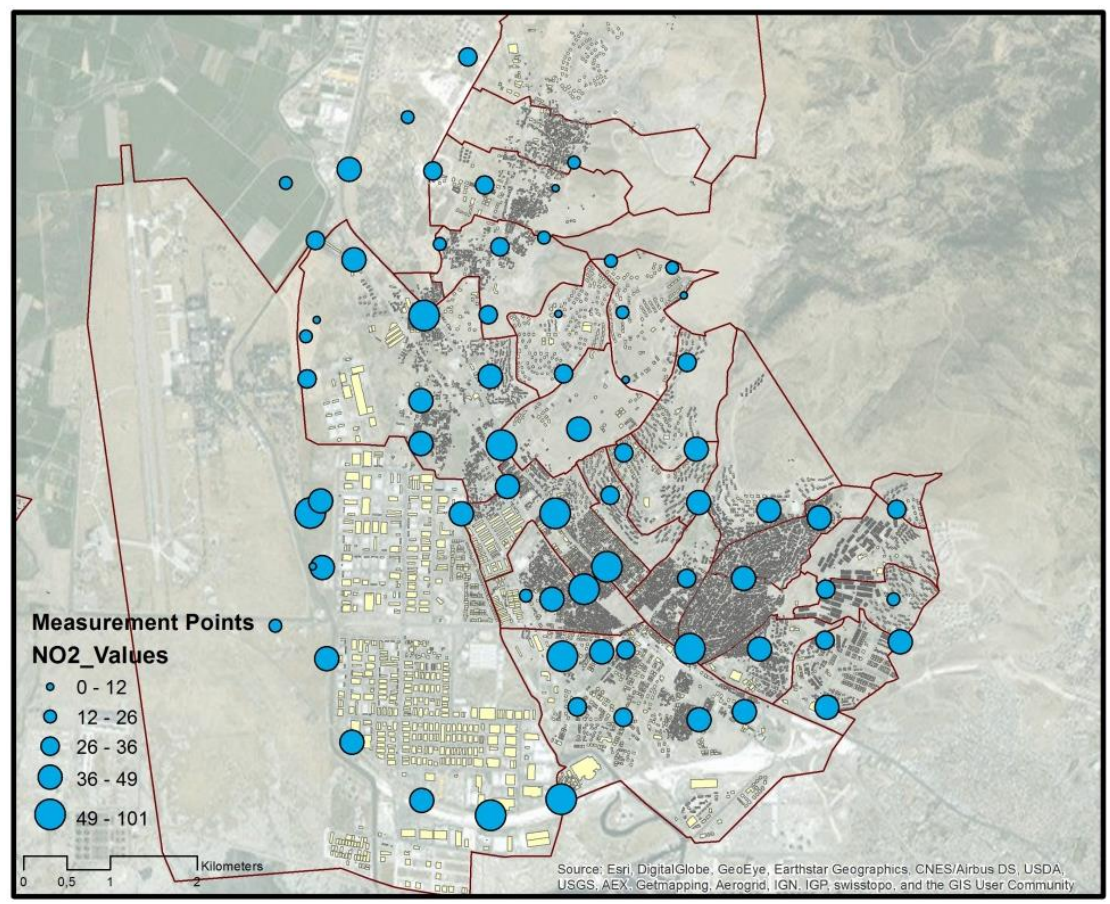

Fig. 3. The observed concentrations for NO2 $(\mu \mathrm{g} / \mathrm{m} 3)$ 


\section{Results}

The results of the Getis-Ord G* local statistics show that there are no points in the data set with low concentrations of $\mathrm{SO} 2$ and NO2 surrounded by higher concentrations. That is plausible since these pollutants diffuse with air. In Fig. 4 and Fig. 5, the observation points that have higher concentrations of SO2 and NO2 concentrations surrounded with points with relatively low concentrations are presented. Z scores of Getis-Ord $\mathrm{G}^{*}$ local statistics are presented. These points have positive Z-scores greater than 1.65 , indicating that they are highly polluted points surrounded by points with lower concentrations, and these results are statistically significant at the 0.10 level.

There are five points with high values of SO2 surrounded by low values (Figure 4). Because of the intensive use of nonnatural gas (coal/wood) for the domestic heating especially in urban renewal areas located in the north-east part of the study area, the usage of incorrect and incomplete combustion techniques in the industrial area located in the west part of the study area and topographical conditions (Misni, 2015, Bayram, 2008, Incecik, 1994, Colls, 2002, Fenger, 2002, Dalyan and İncecik, 2002, Pinto et al.,1998), the level of sulfur dioxide (SO2) concentrations are higher in these points.

There are three points with high values of NO2 surrounded by low values (Figure 5). Due to the increase of motor vehicles in traffic in the study area, dense population and building blocks located in the center and southern parts of the study area, meteorological and topographical factors (Briggs et al., 2008, Mayer, 1999, Ahmad and Aziz, 2013, Lee et al., 2013, Lin et al., 2013, Zbieranowski and Aherne, 2012, Evci, 2009, Yang et al., 2005), the level of nitrogen dioxide (NO2) concentrations are higher in these points.

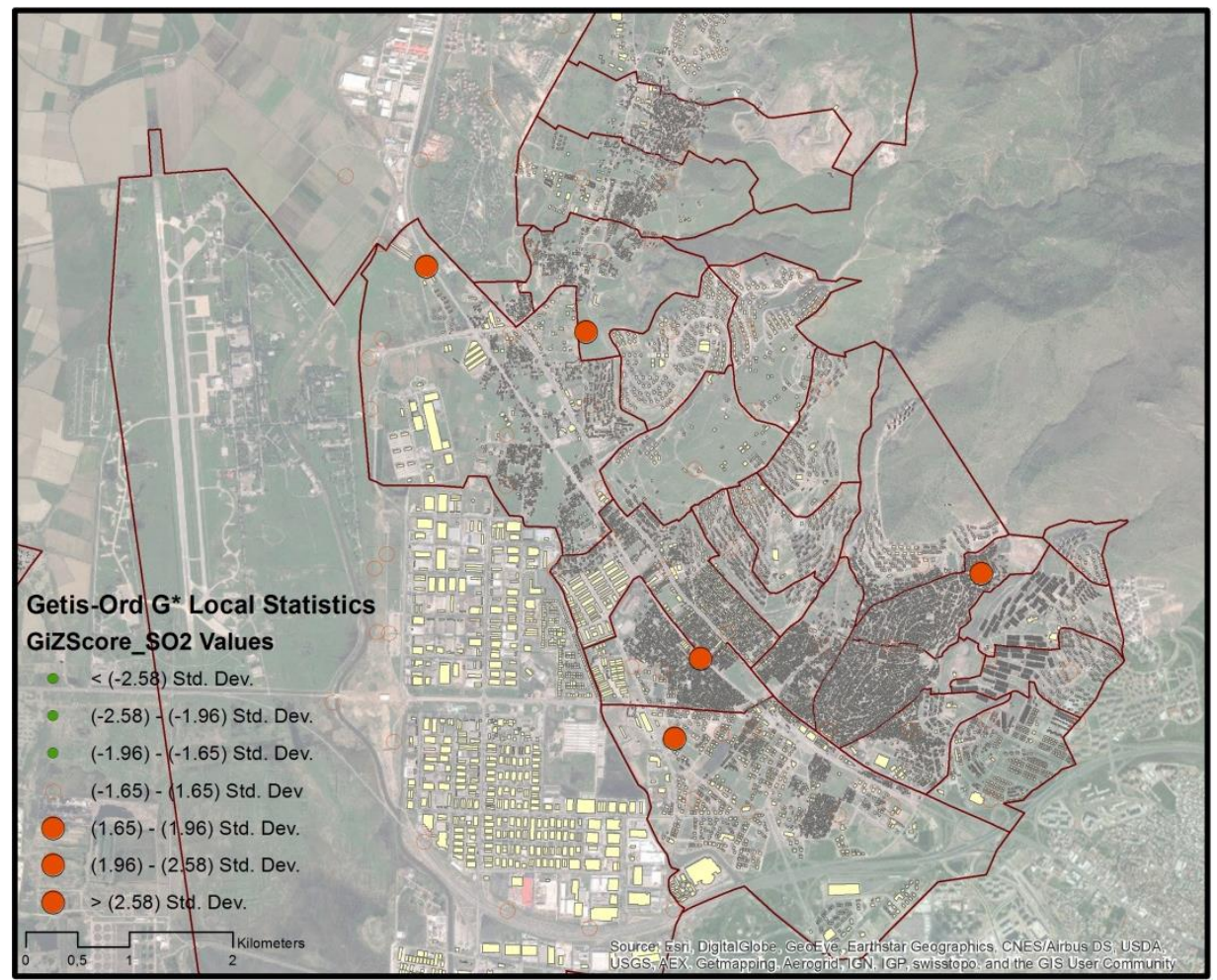

Fig. 4. The hot spots of polluter (SO2) depending on the Z-scores of Getis-Ord G* local statistics 


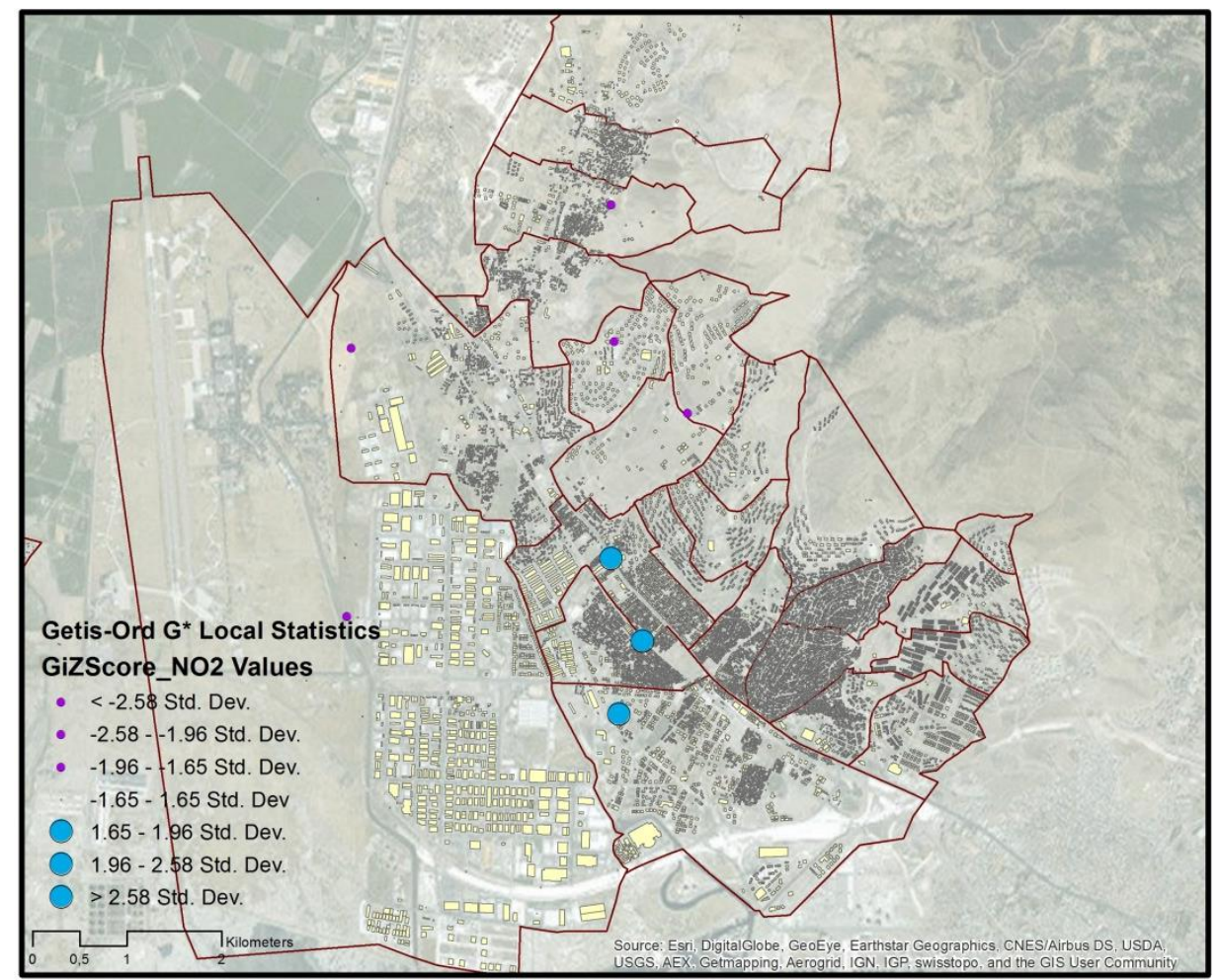

Fig. 5. The hot spots of polluter (NO2) depending on the Z_scores of Getis-Ord G* local statistics

\section{Conclusion and Recommendations}

The aim of the study is to examine the concentrations of two common air polluters (sulfur dioxide (SO2) and nitrogen dioxide (NO2)) with regard to the urban land use decisions. The study area is the district of Çiğli which is located in the northern part of Izmir Metropolitan area. Cigli district has a population of 176.864 by the year 2014 and there exists different land use types such as an industrial zone, a very large recreational area including one of the largest zoos in Turkey, a military zone including a military airport, a regional railway station, commercial areas and residential areas in differing densities in the study area. Sulfur dioxide (SO2) and nitrogen dioxide (NO2) are selected as air polluters in the district and also these polluters' concentrations are measured using passive diffusion tubes at the 80 monitoring sites, exposed for a 2-week period in Cigli in August 2015. In the study area, totally 80 observation points are selected using spatial systematic sampling. Because of different reasons, data from 13 of the passive diffusion tubes were unusable and so there are a total of 67 observations in the data set. As research method, the Getis-Ord $\mathrm{G}^{*}$ local statistic is selected that is a well-known local spatial autocorrelation technique in the analyzing the spatial distributions of the pollution levels.

According to the results of this technique, there are no points in the data set with low concentrations of SO2 and NO2 surrounded by higher concentrations. Therefore, these points with high values have positive Z-scores greater than 1.65, indicating that they are highly polluted points surrounded by points with lower concentrations, and these results are statistically significant at the 0.10 level.

The significant improvements have been seen in urban air quality over the last years and these improvements as urban planning policies aim to improve the quality of life in metropolitan cities. Despite these improvements, the level of air pollutants is still above the acceptable level especially during the winter months. Recently, several precautions have been introduced for the improvement of urban air quality such as the dissemination of the usage of natural gas for domestic heating, the emission controls for the reduction of the level of air pollutants because of dense motor vehicle in traffic and monitoring of coal sales.

There will be important steps in order to solve the urban air pollution problem and to increase the quality of life for the citizens in urban settlement areas, such as more frequent controls for the measurements for air quality in terms of spatial and time tables, improving the control strategies, developing plan decisions in consideration of air corridors, the dissemination of open and green 
areas, encouragement of public transportation and railway transportation type by local governments and realizing studies to minimize carbon emissions and to improve the air quality and controlling over facilities of industrial areas (Deak et al., 2015, Nerriere et al., 2005, Grsic et al., 2014).

This study has some limitations. Firstly, the data used in the study pertains to a limited number of districts in the urban area. A more comprehensive study should consider a larger urban area with a more diverse urban setting. Therefore, the results of the current study reveal that the levels of these two pollutions should be monitored and controlled for improving the quality of life especially in dense urban areas. Additionally, the number of monitoring sites is limited in terms of measuring the polluters' concentrations in urban area. Further studies may include the effects of urban land use decisions on the levels of urban pollutants with regard to various air pollutants in more measurement points throughout Izmir city.

\section{References}

Ahmad, S.S. and Aziz, N., (2013). Spatial and temporal analysis of ground level ozone and nitrogen dioxide concentration across the twin cities of Pakistan. Environment Monitoring Assessment, 185 (4), 3133-3147.

Bayram, A., (2008). Izmir'de Hava Kirliligi. TMMOB Izmir Kent Sempozyumu, 237-244.

Borhan, H., Ahmed, E.M., Hitam, M. (2013). CO2, Quality of Life and Economic Growth in East Asian 8. Journal of ASIAN Behavioural Studies (jABs), Janurary / February 2013: 13-25.

Bouhouras, E., S. Basbas, (2015). Policies towards sustainable city logistics: the case of Thessaloniki. Journal of Environmental Protection and Ecology, 16 (2), $417-423$.

Brauer, M., Hoek, G., van Vliet, P., Meliefste, K., Fischer, P., Gehring, U., (2003). Estimating long-term average particulate air pollution concentrations: application of traffic indicators and geographic information systems. Epidemiology, 14, 228-239.

Briggs, D.J., Hoogh, C., et al., (2000). A regression-based method for mapping traffic-related air pollution: application and testing in four contrasting urban environments. The Science of the Total Environment, 253, 151-167.

Colls, J., (2002). Air Pollution (2nd Edition). Spon Press, England, ISBN 0419206507.

Coşkun, A., (2008). Şehir Atmosferinde Taşıt Emisyonlarından Kaynaklanan Hava Kirliliğinin Belirlenmesi. İstanbul: Marmara Üniversitesi, Fen Bilimleri Enstitüsü, Yüksek Lisans Tezi.

Cubukcu, K.M. (2015). Planlamada ve Coğrafyada Temel İstatistik ve Mekansal İstatistik. Nobel Yayınevi, Ankara.

Daylan, E. and İncecik, S., (2002). İstanbul'da Coğrafi Bilgi Sistemleri ile Hava Kalitesinin İncelenmesi. İstanbul: ITÜ Uçak ve Uzay Bilimleri Fakültesi, Meteoroloji Mühendisliği Bölümü. iTÜ Dergisi, Mühendislik, 1 (2), 51-62.

Deak, G.Y., Tanase, G.S., Daescu, V., Csergo,R., Holban, E., Daescu, A.I., Marinescu, P., Aman, S. (2015). Health-environment relation: a key issue of Romanian environmental protection. Journal of Environmental Protection and Ecology, 16 (1), 304-315.

Dimitrovski, D., Dimitrovski, M., Jovanovski, A., (2015). Natural gas as a fuel in public passenger transportation in urban areas. Journal of Environmental Protection and Ecology, 16 (1),1-6.

El Din, H., Shalaby, A., Farouhb, H.E., Elarianeb,S.A. (2013). Principles of Urban Quality of Life for a Neighborhood, HBRC Journal, 9 (1): $86-92$.

Evci, M., (2009). Determination of ozone, nitrogen dioxide and sulfur dioxide pollution around aliağa by passive sampling. İzmir: Dokuz Eylül Üniversitesi, Fen Bilimleri Enstitüsü, Yüksek Lisans Tezi.

Fan, X., Lam,K., Yu,Q., (2012). Differential exposure of the urban population to vehicular air pollution in Hong Kong. Science of the Total Environment, 426, 211219.

Fenger, J., (2002). Air pollution science for 21. Century: Urban air quality. National Environmental Research Institute, Department of Atmospheric Environment, Denmark.

Getis, A. and Ord, J.K., (1992). The analysis of spatial association by use of distance statistics, Geographical Analysis, 24 (3) 189-206. 
Google Earth Satellite Images, Access Date: August 2015.

Griffith, D.A. (2009). Spatial Autocorrelation, Handbook of Applied Spatial Analysis, 255-278.

Grsic, Z., Dramlic, D., Arbutina, D., Miljevic,N., Dramlic, S., Milutinovic, P., Kaljevic, J., Pavlovic, S., Joksimovic, D., (2014). Representativity of air quality control in limited number of grid points. Journal of Environmental Protection and Ecology, 15 (1), 1-6.

Gunaratna, N., Liu, Y., Park, J. (2013). Spatial Autocorrelation. Journal of Recuperado el, 2, 1 - 14.

Incecik, S., (1994). Hava Kirliligi. Istanbul Teknik Universite Matbaasi, Gumussuyu, Istanbul.

Kocaman, Ö., (2010). Erzurum'da Pasif Örnekleme Yöntemiyle Alansal Hava Kalitesinin Tahmini. Erzurum: Atatürk Üniversitesi, Fen Bilimleri Enstitüsü, Yüksek Lisans Tezi.

Lee, K., Yeom, J., Yoon, C., Yang, W.,et al., (2013). Seasonal and geographic effects on predicting personal exposure to nitrogen dioxide by time-weighted microenvironmental model. Atmospheric Environment, 67, 143-148.

Lin, W., Xu, X., Yu, X., Zhang, X., Huang, J., (2013). Observed levels and trends of gaseous SO2 and HNO3 at Mt. Waliguan, China: Results from 1997 to 2009. Journal of Environmental Sciences, 25 (4), 726-734.

Mansha, M., Ghauri, B., Rahman, S., Amman, A. (2012). Characterization and source apportionment of ambient air particulate matter (PM2.5) in Karachi. Science of the Total Environment, 425, 176-183.

Mayer, H. (1999). Air pollution in cities. Atmospheric Environment, 33, 4029 - 4037.

Misni, A. (2015). The Effect of Building Construction and Human Factors in Cooling Energy Use. Procedia - Social and Behavioral Sciences, AicE-Bs ver. 2: AQoL2014Istanbul ABRA International Conference on Quality of Life Istanbul Technical University (ITU), 202, 373-381.

Mönkkönen,R.U., Srinivasan,D., et al., (2004). Relationship and variations of aerosol number and PM10 mass concentrations in a highly polluted urban environment-New Delhi, India. Atmospheric Environment, 38, 425-433.

Moore,D.K., Jerrett,M., et al., (2007). A land use regression model for predicting ambient fine particulate matter across Los Angeles, CA. Journal of Environmental Monitoring, 9, 246-252.

Mukerjee, S., Willis, R.D., Walker, J.T., et al., (2012). Seasonal effects in land use regression models for nitrogen dioxide, coarse particulate matter, and gaseous ammonia in Cleveland, Ohio. Atmospheric Pollution Research, 3 (3), 352.

Murack, J., (2013). Spatial Autocorrelation Using GIS, IAP 2013: GIS, The MIT Libraries.

Nerriere,E., Navier,D.Z., Blanchard, O., Momas, I., Ladner, J., Le Moullec, Y., Personnaz, MB., Lameloise, P., Delmas, V., Target, A., Desqueyroux, H., (2005). Can we use fixed ambient air monitors to estimate population long-term exposure to air pollutants? The case of spatial variability in the Genotox ER study. Environmental Research, 97, 32-42.

Ord, J.K. and Getis A., (1995). Local Spatial Autocorrelation Statistics: distributional issues and an application, Geographical Analysis, 27 (4) $286-306$.

Ozcan, N.S. and Cubukcu, K.M. (2015). Evaluation of Air Pollution Effects on Asthma Disease: The case of Izmir, Elsevier Procedia - Social and Behavioral Sciences, AicE-Bs ver. 2: AQoL2014Istanbul ABRA International Conference on Quality of Life Istanbul Technical University (ITU), $202,448-455$.

Özgür, E.M. and Aydın, O. (2011). Türkiye'de Evlilik Göçünün Mekânsal Veri Analizi Teknikleriyle Değerlendirilmesi, Coğrafi Bilimler Dergisi, 9 (1), $29-40$.

Pinto, J. P., Stevens,R.K., et al., (1998). Czech Air Quality Monitoring and Receptor Modeling Study. Environmental Science and Technology, 32, 843-854.

Pits,M., Schmid,O., et al., (2008). Seasonal and Diurnal Variation of PM2.5 Apparent Particle Density in Urban Air in Augsburg, Germany. Environmental Science and Technology, 42, 5087-5093.

Querola, X., Alastuey, A., Rodriguez, S., Plana, F., Ruiz, C.R., Cots, N., Massague, G., Puig, O., (2001). PM10 and PM2.5 source apportionment in the Barcelona Metropolitan area, Catalonia, Spain. Atmospheric Environment, 35 (36), 6407-6419.

Reche, C., Viana, M., Pandolfi, M., Alastuey, A., et al., (2012). Urban NH3 levels and sources in a Mediterranean environment. Atmospheric Environment, 57, 153-164. 
Ozcan, N.S., \& Cubukcu, K.M. / 2nd AQoL2015/zmir, Turkey, 09-14 Dec. 2015 / E-BPJ, 1(2) July 2016 (Pp. 178-187)

Shendell, D.G., Therkorn, J.H., Yamamoto, N., Meng, Q., et al., (2012). Outdoor near-roadway, community and residential pollen, carbon dioxide and particulate matter measurements in the urban core of an agricultural region in central CA. Atmospheric Environment, 50, 103-111.

Shi,Z., Shao, L., et al., (2003). Characterization of airborne individual particles collected in an urban area, a satellite city and a clean air area in Beijing.

Atmospheric Environment, 37, 4097-4108.

Turkoglu, H. (2015). Sustainable Development and Quality of Urban Life. Procedia - Social and Behavioral Sciences, AicE-Bs ver. 2: AQoL2014Istanbul ABRA International Conference on Quality of Life Istanbul Technical University (ITU), 202, 10-14.

Vallius,M., Janssen,N.A.H., et al., (2004). Sources and elemental composition of ambient PM2.5 in three European cities. Science of the Total Environment, 337 , $147-162$.

Wehner,B., Birmili,W., et al., (2002). Particle number size distributions in a street canyon and their transformation into the urban-air background: measurements and a simple model study. Atmospheric Environment, 36, 2215-2223.

Yang,F., Ye,B., et al., (2005). Characterization of atmospheric mineral components of PM2.5 in Beijing and Shanghai, China. Science of the Total Environment, $343,221-230$.

Zbieranowski, A.L. and Aherne, J., (2012). Ambient concentrations of atmospheric ammonia, nitrogen dioxide and nitric acid across a rural-urban-agricultural transect in southern Ontario, Canada. Atmospheric Environment, 62, 481-491.

Zhu,Y., Hinds,W.C., et al., (2011). Concentration and size distribution of ultrafine particles near a major highway. Journal of the Air and Waste Management Association, 52, 1032-1042. 